\title{
Institutional Development of Irrigation Management Based on The Local Wisdom in Indonesia
}

\author{
Popi Rejekiningrum ${ }^{1 *}$ and Budi Kartiwa ${ }^{1}$ \\ ${ }^{1}$ Indonesian Agroclimate and Hydrology Research Institute (IAHRI), \\ Indonesian Agency for Agricultural Research and Development (IAARD), Ministry of Agriculture
}

(Received April 9, 2018; Accepted April 29, 2018; Published April 30, 2018)

\begin{abstract}
During 1980-1997, the management of water resources was done with a supply-driven approach. This approach results in the expensive maintenance of water resources and the disregarded resources utilization of environmental sustainability. Since 1998, The Government of Indonesia began to reform institutional irrigation with the financing supported by the World Bank. However, the institutional reforms of the irrigation have not yet reflected the exact changes as expected. Therefore, it is necessary to study the process of strengthening the institutional management of irrigation based on the local wisdom through the inventory of history series of irrigation management policy and empowerment of capacity building and institutional program of irrigation management. This paper presents an effort to develop the institutional irrigation management by exploring the local wisdom in the community. It can be used as a guide for future sustainable management of irrigation.
\end{abstract}

Keywords: agriculture, farmers' union, Subak, Ulu-ulu, water resources,

JEL Classification: B30, Q15, Q25

\section{INTRODUCTION}

In general, the irrigation management policy issued by the government includes the protection of water resources and the arrangement of its utilization. The latest government policy on irrigation management is Instruction of President No. 3 of 1999 on Renewal of Irrigation Management Policy. The policy contains five main contents, as follows: (a) redefinition of tasks, authorities and responsibilities of irrigation management institutions, (b) empowerment of Water User Farmers' Union (P3A); (c) handover of Irrigation Management (PPI) to P3A, (d) payment for operation and maintenance (OM) of Irrigation networks, and (e) Sustainability of Irrigation Systems.

These five policy items are a reflection of the

\footnotetext{
* Corresponding author email: popirejeki@gmail.com, ISSN 2615-6075 online; ISSN 2615-6946 print @UWG Press, 2018

OJS http://publishing-widyagama.ac.id/ejournalv2/index.php/jsed/
}

people's demand for renewal towards irrigation management which prioritizes community participation. All policies are the main programs within the Development and Management of Participatory Irrigation System (PPSIP) as the mandate of Government Regulation No. 20 of 2006 on Irrigation. The implementation of the government policy brings major changes in the pattern of irrigation management, both of roles and responsibilities of irrigation management institutions as well as funding for the operating and maintenance activities of irrigation networks.

In term of technical and socio-cultural conditions in each region, it is necessary to have clear and detailed irrigation management guidelines which are in accordance with local conditions and situations. It is expected that the implementation of OM of irrigation networks are efficient, effective and sustainable through the active role of society and institutional empowerment P3A or the combined P3A. The absence of a legal basis underlying the implementation of guidelines will cause the problem of the transfer mechanism, 
particularly with the extent of coverage, authority, and liabilities in the implementation of irrigation.

During 1960 until the end of 1980, the priority of irrigation water management was the development of resources and infrastructure. Irrigation water management policy was implemented based on the centralized government administration. This was primarily due to limited technical capability. In the second period, end of 1980 to 1997, the management of water resources was carried out by the supply-driven approach that resulted unsustainable in the maintenance and the utilization of water resources infrastructure. The third period coincided the occurrence of monetary crisis in 1997 where the Indonesian government initiated the Water Resources Sector Adjustment Loan Program (WATSAL, Loan No 4469-IND), which was financed by the World Bank.

A large-scale implementation of the institutional reform of water resources and irrigation management is implemented in Java Irrigation Improvement and Water Management Project (JIWMP, Loan No. 3762-IND) and Indonesia Water Resources and Irrigation Reform Implementation Project (IWIRIP, TF NO 027755). However, the institutional reform of irrigation in those three periods has not reflected the expected changes accurately. Therefore, it is necessary to study the process of institutional strengthening of irrigation management based on the local wisdom through an inventory of the historical series of irrigation management policies, capacity building program and institutional empowerment of irrigation management.

This paper presents an effort to develop the institutional of irrigation water management by exploring the local wisdom in the society all over Indonesia so that it can be used as a guideline for water management especially in the sustainable development of irrigation in the future.

\section{DEVELOPMENT OF IRRIGATION MANAGEMENT}

\section{History of Irrigation}

Irrigation support for farming activities has been going on for a long time. In Java, irrigation has been developed since the time of the kingdom before the arrival of the Dutch colonization
(Saptana, Hendiarto, Sunarsih, \& Sumaryanto, 2016). The development of irrigated agriculture for rice crops revealed the Kingdom of Majapahit and Demak as rice exporters. On another area, Bali has also already constructed traditional irrigation buildings long before the colonization period. The local name of the irrigation of Subak still functions well with the several improvements.

During cultivation system (Dutch: culturstelse) under Dutch colonization in the mid-19th century, a large number of the irrigation infrastructure were built. The large irrigation networks whose a strong construction was developed by the Dutch government. As an illustration, the area of technical irrigation in 1885 as a result of cultivation system reached about 210 thousand hectares. The development of irrigation in this period was considered to be the beginning of technical development and irrigation development.

In the following periods, the intensification program on rice farming encouraged the development of more demanding irrigation networks. The program included rehabilitation and upgrading of irrigation networks, construction of large dams, construction of new irrigation networks, and construction of tidal irrigation networks. As a result, the rice production had increased sharply in 1984 in which it exceeded the amount of national rice demand and achieved selfsufficiency in rice.

The irrigation infrastructure also plays an important role in increasing a sugar production. The growth of plant cane requires an abundant amount of water in the dry season, especially for tillage, plant seedling, and maintenance. Thus, irrigation development has increased the productivity of sugarcane in many estates. This also affects the increase of sugar production at the national level and the improvement of national sugar industry performance. Such description proves the willingness of sugarcane plantation companies to finance the construction of irrigation and reservoirs with large amounts of funds.

Furthermore, the development of irrigation institutions cannot be separated from the traditional irrigation development. The existing irrigation institutions are a continuation of the development of existing traditions. The existence of 
an irrigation institution is strongly influenced by local geographical features, the development of agricultural cultivation and the government's strong interference with the policy of irrigation water management institutions.

In Indonesia, one of the well-known irrigation heritages is Subak in Bali and some places in Java. This irrigation is generally located on the surface of the sloped land, which has high erosion potential, with a relatively small management area. Physically, the small irrigation is not able to survive in the long run due to the inundation process, erosion and landslide by surface run-off. Centralized and general government policies have reduced local irrigation management institutions although some still survive today such as Subak in Bali. It revealed (Pasandaran \& Taryoto, 1993) that irrigation policies that are detached from local norms often face obstacles.

Subak is a manifestation of the interaction of a collection of characters of irrigation society, agricultural production units, autonomous entities and religious communitie (Freedman \& Geertz, 1965). The results of a study of (Windia, Pusposutardjo, Sutawan, Sudira, \& Arif, 2005; Windia, Sumiyati, \& Sedana, 2015) show that Subak system can support agri-business and agroindustry oriented the farming system. Furthermore, it suggests that Subak in Bali has potential as an embryo of rural economic institutions. The Subak system contains written rules in the Balinese language called awig-awig and unwritten rules in the Balinese language called perarem based on the local culture.

The rapid development of irrigation occurred at the beginning of the twentieth century after the introduction of ethical politics by the colonial government. In this period, modern irrigation system through the use of technology was applied in the lowlands for overcoming the famine that occurred in Central Java. It should also be noted as foundation framework of the establishment of an irrigation organization during the colonial period, including (1) the working area of the irrigation organization does not follow the administrative territory but is based on the OM of the irrigation network; (2) separation of construction work affairs from units dealing with the exploitation and maintenance of irrigation; (3) understanding the irrigation system requires a review of the integrated irrigation network development planning process (Pasandaran, 1991).

The development of irrigation institutions has shaped the institutional and socio-economic dynamics of rural communities in several regions of Indonesia. The linkage between the development of irrigation (physical) and institutional (irrigation system) technologies creates a new institutional formation process. Based on the argument above, institutional manifestations require the support of the rule of law to regulate economic activity in society.

According to (Ambler, 1992), the water management organization is not only for technical activities, but rather regulates the utilization of irrigation building facilities. Water use activities in traditional farming establish a profit-sharing culture. Workers who assist with water management receive profit sharing in kind. In Java, it has still found the traditional culture of profitsharing such as ceblokan, kedokan, and bawon.

The irrigation technical network has various characteristics. Based on the size scale, The irrigation network is divided into three groups, including (i) large-scale irrigation such as Brantas watershed and Jatiluhur watershed; (ii) mediumscale irrigation such as Sadang reservoir in South Sulawesi; and (iii) small-scale irrigation such as the Leuwinangka reservoir in Subang Regency. On a large scale, irrigation water management in primary networks (reservoirs, primary and secondary channels and supporting buildings) is under the management of Perum Jasa Tirta I for Brantas watershed and Perum Jasa Tirta II for Jatiluhur watershed. In which Perum Jasa Tirta does not operate, the irrigation management conducted by public works office (Dinas PU Pengairan). Meanwhile, the tertiary irrigation networks are handed over by the management of P3A institutions and the P3A Association.

On another region, lowland and rainfed lowland irrigation areas, farmers independently develop the pump irrigation. The pump irrigation system is generally held by the private sector, governmentformed farmer Group and NGO-oriented farmer Group. The existence of P3A in pump irrigation management is to assist farmers when negotiating 
with investors the owner of pump irrigation (Supriadi \& Rivai, 2018; Syahputra, 2013).

\section{Flashback of Irrigation Policy}

The government policy during the Pelita I and II periods (1969-1979), the attention was focused on the rehabilitation and construction of new irrigation systems to support the achievement of rice selfsufficiency programs. The policy then continued on Pelita III-IV (1979-1989) which was accompanied by the consolidation in the institutional management of irrigation water to maintain the rice self-sufficiency (Sumaryanto, 2016). Furthermore, during the Pelita V-VII period with the implementation of regional autonomy, there is a tendency for a legal aspect to irrigation water management at farmer level (tertiary plot). It is operated by the P3A and the P3A Association (secondary plot) which should replace the government tasks in the operation and maintenance of the irrigation network.
In the framework of guidance to farmers, the government issued Instruction of President No. 2 of 1984 which basically gave direction to all relevant agencies in guiding farmer organizations in using existing irrigation water for the agricultural development. Moreover, the policy was described in the Permendagri No. 12 of 1992 concerning the establishment of a farmer organization handling the irrigation management called the Water User Farmers Union (P3A). Since the mid-1980s, the central government began to formulate a strategy to form a farmer organization (P3A) which was expected to help manage the irrigation networks. Even since the late 1990s, a number of small irrigation networks (under 500 ha) have been handed over to farmers through the Small Irrigation Transfer Program (Program Penyerahan Irigasi Keci//PIK).

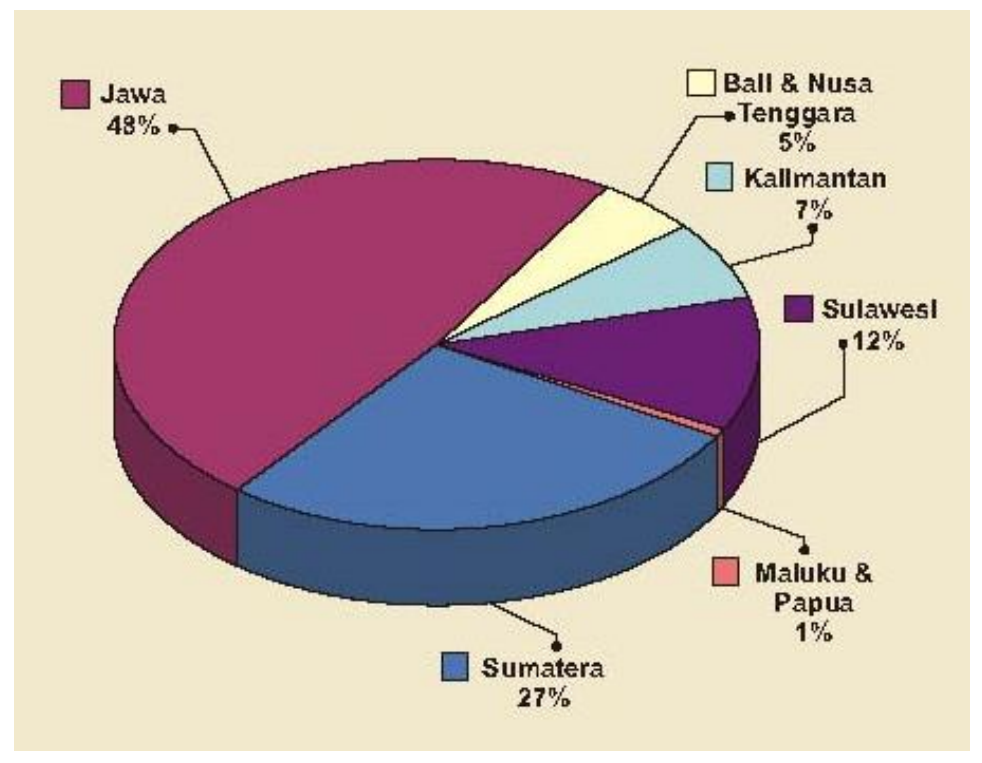

Figure 1. Distribution of irrigation networks in Indonesia (Kemen PUPR, 2015)

The implementation of P3A and P3A Association by the government through the Public Works Authority tended to pursue quantity targets and ignoring the quality aspect. In fact, P3A and P3A Associations are not ready to do operation and maintenance of irrigation although it is limited to a tertiary network. The fundamental weakness of the process of establishing and developing P3A/P3A
Association is more project-oriented approach and not through an integrated social process. Therefore, once the program is finished, the existence of irrigation water management institutions is questionable.

Instruction of President No. 3 of 1999 on the renewal of irrigation management is felt to be very 
unfair. The rule states that P3A / P3A Association has authority in primary, secondary and tertiary channel OM activities, but funding is derived from water management fee (IPPAIR and P3A contributions) from farmers. This suggests that Delegation of authority remains unclear with respect to a legal basis, implementation guidance and institutional preparedness of P3A

General guidelines for implementation of P3A institutions cover one sub-district area, while the P3A Association includes one District. In Central Java, the establishment of the P3A Association is based on a hydrological unit (secondary channel). The results of (Saptana et al., 2016) in Sidrap, South Sulawesi, indicates that the establishment of the P3A Association has a pattern as found in East Java.

The results of a research by (Saptana et al., 2016) state that the water allocation of irrigation obtained through four patterns: (i) performance of irrigation management at farmer level is very diverse and irrigation water allocation is still not optimal; (ii) large scale irrigation network management systems implemented through regional water distribution based on the water class system; (iii) small and medium irrigation water management systems implemented through water distribution with rotation between upstream, middle and downstream rice fields; (iv) in all systems, irrigation networks of farmers are not ready to bear the burden of irrigation operations and maintenance, where farmers face high prices of input and low prices of agricultural products.

Based on the existing regulatory policies in term of irrigation management in many locations in Indonesia, it shows that the development of irrigation water is not based on the local culture. The developed program is more centralizedoriented and only intended to cover costs of the operation and maintenance of irrigation networks. The irrigation management should be directed to become an independent rural economic institution, especially in regional autonomy.

\section{Farmer Perception}

Farmers' perceptions of irrigation water determine how far farmers appreciate the irrigation water. If farmers consider that irrigation water is an economic good, then they will use it more efficiently. Conversely, if water is still considered not economic goods then the efficiency efforts in the utilization of irrigation water is difficult to be realized.

The results of a research by (Saptana et al., 2016) provides some basic information as follows: (i) there has been a friction in farmers' perceptions regarding water as public goods towards water as an economic good; (ii) the perception of farmers who regard water as an economic good is increasingly evident in relatively water-poor areas of rice fields; (iii) the economic calculations are actually applied to semi-technical irrigation rice areas, simple irrigation and rainfed rice fields that use pump irrigation.

\section{THE LOCAL WISDOM IN THE IRRIGATION MANAGEMENT}

\section{Period of Old Javanese}

A historical record of the use of irrigation water for agricultural cultivation is found in ancient inscriptions and writings (Prabowo, Arif, Putra, \& Cahyono, 2006). King Sri Maharaja Airlangga issued a written order in the form of inscription Kelagen (1037 AD) in the hamlet Kamalagyan or Kalagyan, Tropodo Krian (Sidoarjo). The inscription is located close to Bengawan Purba Telung. The main content of the inscription is the command of Sri Maharaja Airlangga so that the people work to create a reservoir (tambak, dawuhan) to withstand the flow of Bengawan Terung river flood. Floods cause damage to the crop, worship places, sima (prone land) and transportation routes to Hujung Galuh Harbor thereby lowering taxes for the kingdom. Airlangga's success in building Bengawan Terung dike is able to restore tax revenues, support from farmers, traders, and religious leaders.

The Canggu inscription was found Canggu Village, Kediri in the year of 1358 . The inscription stated the designation of the Canggu region as the sima of the Brantas River (Cahyono and Suprapto, 1999, in Prabowo et al., 2006). The consequence of the establishment of the sima region was the tax exemption from Majapahit kingdom. Along the Brantas River, there were many sima called nadi tira pradesa or riverside villages that managed trade in the Brantas River. Nadi tira pradesa is thought to have grown into a kind of an autonomous area of watershed management 
directed by the royal center. Similarly, the profits are handed over in the form of tribute to the royal center (Prabowo et al., 2006).

The Rakai Warak Dyah Manara of the Mataram royal authority based in Central Java has been published. Harinjing inscription in Saka 726 (804 $A D)$. The text of the inscription explains that the dam construction was carried out by Bhagawanta Bari on the Harinjing River (Prabowo et al., 2006). As a result of the development of the dam (dawuhan), the land owned by Patih Atuha (patih kingdom of Mataram in East Java named Dapu Bhi) covering 1 (one) flood plot has turned into a small reservoir. Another benefit of the existence of dawuhan is the community land get irrigation water, thus generating people's welfare and tax revenue for the state. For his efforts, Bhagawanta Bari was then awarded a piece of land / swatantra (sima). Meanwhile, the land belonging to Dapu Bhi who was inundated due to the construction of dawuhan, the kingdom gave compensation.

\section{Airlangga Kingdom}

During the King Airlangga was in control, there was a technological development related to the river water management technology. The explanation of the river water management technology documented in Kamalagyan Inscription in 1037. Kamalagyan inscription contains the tax reductions and construction of water buildings in Waringin Sapta area. The inscription told about the royal policy related to tax reductions in Kamalagyan and surrounding villages. Tax reduction in Kamalagyan, Kalagyan Sandungan, and Kakalangan villages will be the people's incentive to maintain dam benefits in Waringin Sapta.

Kamalagyan inscriptions provide preliminary information on water management during the King Airlangga periods which is distributed for the benefit of the people, namely: (i) the reduction of taxes by the kingdom was for the interest of dam construction; (ii) the Brantas River often caused the occurrence of floods so that some downstream villages and sacred buildings are affected; (iii) the immediate impact of floods was the decrease in agricultural production which in turn results in reduced taxes to the kingdom; (iv) because the people had tried several times to build the dam but always failed, then the king mobilized all the people to build the dam again; (v) the positive impact of dam construction was that the dam actually facilitates trade and transportation along the Brantas river; (vi) another positive impact was the resumption of agricultural land cultivation; (vii) because of the success, the dam was named Dawuhan Sri Maharaja; (viii) residents around the dam were involved in maintaining the safety of the dam; and (ix) the inscription also contained praise for the king's leadership as the queen cakrawati

\section{Irrigation in Java, 1800-1950}

During the early period of the Dutch colonialism, rice was already a major source of carbohydrates for food, and most people depending on the rice cultivation. Increased rice production is supported by irrigation facilities such as reservoirs, dikes, and canals. Although irrigation facilities in supporting the fulfillment of food production were available, the colonial government planned in 1950 had been achieved a technical irrigation system with 1.3 million hectares area.

The process of achieving the technical irrigation program was divided into 3 stages, as follow: (i) the period 1830-1885 was the phase of physical construction of the network facility; (ii) in 18851920 was the establishment of the irrigation system; (iii) the period 1920-1942 was the steady operation of the system.

During the stage of achievement of the process, there was always a reciprocal interrelation between the Western technology and the local technology. The irrigation system was a joint venture with ownership or control to seek relatively low profits. The advantages in this regard included if the irrigation facility was privatized. At this stage, there was also a clear division of responsibility that was primary network facilities (dike, main channel), conducted by Dutch engineers as planners.

Meanwhile, the local farmers were responsible for tertiary channels to the land plots. After the initial phase of cooperation had been going well and mutual trust over the results of each work, then the local farmers began to be involved in the management. The involvement of local people provides experience and enhances technological understanding in irrigation management. The Dutch engineers learned from the local technology 
(e.g. natural reservoirs and water distribution methods) including design methods. Farmers also learned from the western technology, for example in understanding the quality of construction materials according to the design.

\section{During The Old Order Government to The Reform Order}

Free intake approach remains the most widely used by the community to take water from the river. This approach is simple, easy, and inexpensive to construct irrigation infrastructure. A free intake commonly uses material rocks that available along the river. However, later plastic sacks filled with sand are more often used because the stone becomes a valuable commodity to sell. This case occurs in the flow of the Logawa River (Banyumas), Elo (Magelang), and Pabelan (Magelang).

Community in the upstream Logawa River took the initiative to built a free intake passing through the ridge of Mount Slamet along the $16 \mathrm{~km}$. This effort resulted in Kalpataru award from the New Order government in 1998. The current condition of the irrigation still operates well. On the downstream area of Magelang, the irrigation network use permanent construction by the District Government in the form of concrete construction cast, with coverage area about 600 ha. The free intake of the Pabelan River use the material of sandstone and sand sandblast and able to irrigate a 10 ha of the rice fields. This shows a collaborative illustration of mutual support between the community and the government.

Collaboration between the community and the government in the irrigation management has been established since the colonial period. In Magelang District, Central Java before 1995, there were many Rural Irrigation Areas (Daerah Irigasi Pedesaan/DIP) that constructed their own network system cooperating with the government's Village Irrigation Development (Pengembangan Irigasi Desa /PID). Currently, village irrigation networks are in the form of the permanent building. Before, the non-permanent dikes buildings had been widely used since colonial or earlier (Gelpke, 1976, van Setten van der Meer, 1979 in Prabowo et al., 2006), for example from bronjong wire or bamboo, a pile of wood, or banana stems. The construction of village irrigation networks with permanent buildings is recognized to produce a water withdrawal efficiency. This creates irrigation water collection from the upstream area intensively. This often causes the volume of the river flow to decrease and the to slows down.

\section{THE LOCAL INSTITUTION OF THE IRRIGATION}

Values and traditions of life work together found in society in Indonesia. One such tradition is referred to as gotong-royong. Gotong-royong means cooperating with each other among people in the region. The tradition of gotong-royong is also found in the management of water resources, including irrigation.

Local institutions of this irrigation grow and operate in accordance with the dynamics of development. A well-known local institution is Subak in Bali and in some areas of Lombok. Other institutions that can still be traced to their existence include Panriahan Pamokkahan in North Sumatra and Panitia Siring in South Sumatra and Bengkulu. At the end of Pelita V, the institutional Panitia Siring -siring (channel) can be found in some rural irrigation areas. These traditional institutions are better known as office positions in village government administration. The holder of the position sets the pattern of cooperation in the management of irrigation water, for example, Uluulu in Central Java, Ili-Ili in East Java, Tuo Banda or Siak Bandar in West Sumatra, Raksabumi in West Java, Malar or Ponggawa in Sumbawa, Tudung Sipulung in South Sulawesi and Kejruen Blang in Aceh.

The existence and role of local institutions are increasingly stronger with the support from the government (Rachman \& Kariyasa, 2002). The government directs the local institutions to transform into an organization called Perkumpulan Petani Pemakai Air (P3A), which means Water User Farmers Association (WUA). However, the establishment of WUA is trapped in the projectbased approach rather than improving the effectiveness and institutional sustainability in the irrigation management. It creates a new awareness has emerged that the role of local communities and their participation in the entire development process. The government has established new 
policies in the irrigation management that prioritize the interests of the farming community. Water user farmer associations are positioned as the key decision makers and all at once as the actors that are responsible for irrigation management.

\section{Subak}

The existence of the subak tradition can not be separated from the very strong tradition of the Balinese community hereditary of kings' traditions in Bali who recognize their land rights and water acquisition for those who clear land. This institution also can not be separated from its relation with the belief of their Hindu religion. The rules of Hinduism are used as the basis for guidance (awig-awig) for subak in carrying out its activities.

Subak activities include operation and maintenance, as well as the irrigation water management combined with an agricultura cultivation, such as determining planting schedule and watering schedule, plant species, crop rotation, pest control efforts and other aspects. Subak serves its members by establishing complete irrigation networks, from dikes (empelan), ducts (kecabah), tapping buildings (tembuku), water dividers (pemaron) and other related matters.

In colonial periods, the number of Subak institution reached 2.484 and then decreased to 1.230 in 1951 with 96.243 hectares of acreage area. The decreased amount of Subak due to government activities in the improvement of irrigation network by combining Subak network into a larger irrigation network. The development of an agricultural land lease system and the degradation of irrigation infrastructure increase the pressure to the Subak in operating and distribution water so that the number of Subak decreases. In line with the phenomenon, there is also an increased occurrence in water tapping on one river by several Subak. This encourages the government's intervention to regulate water allocation through various ways so that the limited water can be shared equitably and fairly.

Massive and significant improvements occurred when the government implemented an irrigation development and rehabilitation program during 1979 to 1990 . The program covered an irrigation network on an area of 45 thousand hectares. It covered almost all irrigation networks in Bali that had more than 100 hectares per unit management. These comply with the applicable condition for the construction of modern irrigation networks. Through the program, the government had also carried out a series of efforts to improve the capability of Subak, including technical, management, and as well as its organization. Merging several Subak required the management, operation, and maintenance aspects that should be improved.

At the beginning of the program, the improvement of irrigation in Bali became problems. It triggered conflicts among Subak. These conflicts continued from generation to generation. The government implemented more technical and economic approaches rather than local religious and cultural approaches. Some irrigation networks were combined into a larger irrigation network with a building size that considered only efficiency factors regardless of the history and background of Subak, culture, and religion. Based on these experiences, in the next period of irrigation network development and the improvement of the government, it is considered not only technical and economic approach but also concerns the cultural and traditional approach.

\section{Ulu-Ulu}

The Ulu-ulu is a village institution that has existed before the colonial period. The name of Ulu-ulu was derived from the name of the position of a village official who was assigned to take care of irrigation, including arranging the distribution of water to farmers' fields, organizing mutual cooperation to maintain channels and irrigation buildings, and communicating and reporting to the head of the village as well as irrigation officers.

Ulu-ulu can be found almost all over Java with different names, except in Pemali Comal with the division of the ulu-ulu system. Sometimes there are several variations in the mechanism of the work of ulu-ulu. But in general, there are similarities, the position ulu-ulu selected by the community as part of village autonomy. The working area of ulu-ulu follows the boundaries of village administration.

Now, the ulu-ulu became a member of the village pamong and is a subordinate of the head of the village. As the village officials, ulu-ulu generally granted the right to manage on a plot of land 
(bengkok). The acreage of the land varies from one to three balls. Not all ulu-ulu villages are granted with bengkok, some of them get compensation in the form of salary either annual or seasonal in accordance with the land area of their responsibility.

\section{Raksabumi}

In several areas of West Java such as Cirebon, Indramayu, Kuningan, and Majalengka were found the existence of a village officer called raksabumi. His duty was to manage everything related to land use, including irrigation. It was estimated that raksabumi had emerged since the Dutch colonialism as happened at the ulu-ulu. Raksabumi as a village officer generally is granted with bengkok. They also have the right to hire 0.5 hectares of village land at a half price. Due to limited availability of land, some of them did not get bengkok but they earned a salary. During 1945-1950, raksabumi acquired bengkok of 3.5 hectares. Because the area of agricultural land decreased, the area of bengkok given to raksabumi in 1990 decreased to 3 hectares. But, they still receive a right of land rent of 0.5 hectares at half price.

In the irrigation management, the raksabumi generally have close relationships with irrigation technician and raksabumi from the surrounding villages, especially villages that use water from the same water sources. Where water crisis happened, raksabumi should be able to divide water equitably, fairly, and securely. Raksabumi should often look for alternative water sources such as rivers or drainage channels that may be tapped to increase water debit for the benefit of people.

At the end of Five Years Development Stage I (Pelita I), the existence and roles of the raksabumi experienced a small change along with the establishment of P3A. Those years were a transitional period in which raksabumi still existed together with P3A had begun to be established. Some of the changes were related to compensation of bengkok land and salary. Raksabumi received only 0.3-1 hectare bengkok, or a salary equal in kind (rice) of about $20-25 \mathrm{~kg}$ per hectare. Many regions provided both the compensation of bengkok and in kind respectively. The availability of agricultural land and land productivity took into account in the provision of bengkok and salary. In the last 1979, raksabumi had been transformed into the Head of Economic Affairs of Development and Cooperation which was in charge of all things related to the village economic development.

\section{Tuo Banda or Datuak Ampek}

The area of West Sumatra is mostly a mountainous area. Therefore, the rice fields developed by the government and the community are generally small. The tradition of establishing irrigation areas has long been owned by the communities in the area.

For the Minang community, especially the tetua nagari (village leaders) - and its farmers, the figure of tuo banda as irrigation water manager is common. According to them, to manage the channel, the traditional leaders and penghulu leaders appoint a person who is trusted to be a tuo (head/leader). Tuo Banda is given the right to regulate water in the rice fields, and solve all problems arising from irrigation. He is finally called as tuo banda, which eventually becomes the traditional institution of irrigation management in West Sumatra. Similar institutions also exist in North Sumatra under the name of raja bondar.

The name of these traditional institutions varies for each nagari. However, the name of tuo banda is widely used in most of the nagari. Someone can be chosen as tuo banda is a person who works as a farmer, mature enough, respected for his honesty and authority.

This tuo banda institution has been known since the Dutch colonial era. The traditions and cultures have still obeyed by ninik-mamak and penghulu in each nagari. The existence and role of tuo banda in managing irrigation at the village level is recognized by the colonial government. The tuo banda's duties are formalized in the form of the written document including to maintain the irrigation network, to distribute water and to implement the activities related to water use.

During the war of independence until the implementation of Pelita I, the role of tuo banda gradually diminished, following the changes occurred such as kenagarian then was divided into several villages. The role of ninik-mamak also gradually diminished along with the dynamics of 
the time. The selection of tuo banda which was usually carried out by ninik-mamak, penghulu, and the community by consensus and agreement is now rarely carried out. Now, the election of tuo banda is officially conducted through P3A with the guidance of the village head.

\section{Water User Farmers' Union (P3A)}

The existence of local irrigation institutions is experiencing dynamics following the need of increasing agricultural production. Organizations of local institutions tend to be specific according to social and environmental conditions. This often shows a difference in performance when implementing a central government program.

As explained before, Ulu-ulu as a traditional institution shows a tendency as a non-formal organization. Ulu-ulu does not have a standard organizational structure and clear provisions and sanctions. Meanwhile, Subak can be considered as a formal institution, because it fulfills provisions of an organization in general.

Around 1950, in Sragen, Central Java. an irrigation institution emerged under the name of Persatuan Air Surakarta (PAS). The institution then spread to several regions under the name of Dharma Tirta. PAS is believed to be an embryo for the establishment of existing P3A. The establishment of PAS could not be separated from the problems of damage to irrigation infrastructure and the low volume of water availability. This situation often causes disputes among farmers. To accomplish this, some village administrators form PAS with a clear organizational structure and include sanctions provisions to be imposed.

Furthermore, in 1967, PAS succeeded in repairing almost the entire irrigation network. In 1968, the Governor of Central Java changed the name of PAS to Dharma Tirta. Dharma Tirta institution was then adopted into P3A and continues to grow in some areas with good performance.

The existence of local institutions such as Subak, village ulu-ulu, raksabumi, tuo banda, raja bondar was more stable with the issuance of PP. 23 of 1982 on Irrigation. This is reinforced by the issuance of Instruction of President No. 2 of 1984 dated January 26, 1984, and Regulation of the
Minister of Home Affairs No. 12 of 1992 which regulated the guidance and establishment of P3A.

With the enactment of Goverment Regulation No 77 of 2001, the presence of local irrigation management became more recognized. The regulation affirms that $\mathrm{P} 3 \mathrm{~A}$ or $\mathrm{P} 3 \mathrm{~A}$ associations are organizations for water user farmers in an irrigation service area, including local irrigation management agencies. The existence of local irrigation institutions such as Subak became more recognized. The regulation states that $\mathrm{P} 3 \mathrm{~A}$ is a general term for irrigation management organizations that recognize the position of local irrigation management in different areas.

\section{CONCLUSION AND SUGGESTION}

Irrigation development strategies as supporting infrastructure for agricultural development can not be fully implemented centrally or using a single pattern. The strategy should be able to solve the problem by considering the socio-cultural aspects of the local environment.

Development of irrigation water management not only emphasizes the achievement of quantitative growth and physical goals but also more emphasis on community empowerment.

Efforts to empower communities in the management and conservation of water resources are conducted by exploring local wisdom in people's lives and building awareness about the value and benefits of water resources.

\section{REFERENCES}

Ambler, J. S. (1992). Irigasi di Indonesia: Dinamika kelembagaan petani. Jakarta: LP3ES Lembaga Penelitian, Pendidikan dan Penerangan Ekomomi dan Sosial (Indonesia). Retrieved from

https://books.google.co.id/books?id=Ibs1AgAA $\underline{\text { CAA] }}$

Freedman, M., \& Geertz, C. (1965). Agricultural Involution--The Process of Ecological Change in Indonesia. Population Studies, 18(3), 331-332. https://doi.org/10.2307/2173295

Kemen PUPR. (2015). Rencana Strategis Kementerian Pekerjaan Umum dan Perumahan Rakyat Tahun 2015-2019. Jakarta: Kementerian Pekerjaan Umum dan Perumahan Rakyat. Retrieved 
https://www.pu.go.id/source/Renstra-20152019.pdf

Pasandaran, E. (1991). Irigasi di Indonesia: Strategi dan pengembangan. Bogor: Lembaga Penelitian, Pendidikan dan Penerangan, Ekonomi dan Sosial. Retrieved from https://books.google.co.id/books?id=kAYXAAAA IAA]

Pasandaran, E., \& Taryoto, A. . (1993). Petani dan Irigasi: Dua sisi mata uang. In Lokakarya Pembangunan Berkelanjutan dan Penanggulangan Kemiskinan di Tingkat Lokal. Bogor 15-17 Juni 1993: Pusat Penelitian Sosial Ekonomi Pertanian, Badan Penelitian dan Pengembangan Pertanian. Bogor.

Prabowo, A., Arif, S. S., Putra, H. T. A., \& Cahyono. (2006). Kolaborasi pemerintah dan masyarakat: sejarah perjalanan irigasi di Indonesia (Periode Kerajaan sampai Reformasi). In Seminar Hari Air Dunia XIV. Jakarta: Dirjen Pengelolaan Lahan dan Air Departemen Pertanian. Retrieved from

http://www.ampl.or.id/digilib/read/kolaborasipemerintah-dan-masyarakat-sejarahperjalanan-iriqasi-di-indonesia-periodekerajaan-sampai-reformasi-/146

Rachman, B., \& Kariyasa, K. (2002). Dinamika kelembagaan pengelolaan air irigasi. SOCA (Socio Economic of Agriculture and Agribusiness), (3), 1-15. Retrieved from https://ojs.unud.ac.id/index.php/soca/article/vie w/4000/2990

Saptana, N., Hendiarto, N., Sunarsih, N., \& Sumaryanto, N. (2016). Tinjauan Historis dan Perspektif Pengembangan Kelembagaan Irigasi di Era Otonomi Daerah. Forum Penelitian Agro Ekonomi, 19(2), 50-56. https://doi.org/10.21082/fae.v19n2.2001.50-65

Sumaryanto, N. (2016). Peningkatan Efisiensi Penggunaan Air Irigasi Melalui Penerapan Iuran Irigasi Berbasis Nilai Ekonomi Air Irigasi. Forum Penelitian Agro Ekonomi, 24(2), 77. https://doi.org/10.21082/fae.v24n2.2006.77-91

Supriadi, H., \& Rivai, R. (2018). Pengembangan Investasi Irigasi Kecil untuk Peningkatan Produksi Padi Mendukung Swasembada Beras. Analisis Kebijakan Pertanian, 16(1), 43-57. https://doi.org/10.21082/akp.v16n1.2018.43-57

Syahputra, B. (2013). Model pompa air dengan tenaga angin untuk pemanfaatan irigasi sawah. In Prosiding Seminar Nasional Sains dan Teknologi Fakultas Teknik (Vol. 1, pp. 51-56). Universitas Wahid Hasyim Semarang. Retrieved from

https://publikasiilmiah.unwahas.ac.id/index.php /PROSIDING SNST FT/article/view/755/867

Windia, W., Pusposutardjo, S., Sutawan, N., Sudira, P., \& Arif, S. G. (2005). Sistem Irigasi Subak dengan Landasan Tri Hita Karana (THK) sebagai Teknologi Sepadan Dalam Pertanian Beririgasi. Soca (Socio-Economic of Agriculturre and Agribusiness), 5(3), 1-15. Retrieved from https://ojs.unud.ac.id/index.php/soca/article/vie $\underline{w / 4095}$

Windia, W., Sumiyati, \& Sedana, G. (2015). Aspek Ritual pada Sistem Irigasi Subak sebagai Warisan Budaya Dunia. Jurnal Kajian Bali, 5(1), 23-56. Retrieved from https://ojs.unud.ac.id/index.php/kajianbali/articl e/view/15721 